\title{
Effect of Temperature on the Performance of Rheofloc: Conductivity Removal from RO-reject
}

\author{
JC van der Linde, E Fosso-Kankeu*, G Gericke, F Waanders and T. Tamane
}

\begin{abstract}
South Africa is an arid country with an annual average rainfall less than half of the world's average rainfall. The industrial sector uses $11 \%$ of this limited amount of water. Eskom is one of these users. Within the water treatment system at the Grootvlei power station, reverse osmosis (RO) is used. The retentate from the membranes is pumped into a sump. This water can be treated for further usage, which ensures that the plant abstracts less water from the environment. Rheofloc, an inorganic polymeric flocculant was used in this study in conjunction with lime treatment, to reduce the conductivity of the water. As the conductivity decreases, the number of ions in the water decreased. The jar test method consisted of the addition of the coagulant and flocculant during rapid mixing for 5 minutes at $240 \mathrm{rpm}$, thereafter the lime was added to increase the pH to 10.1 during slow mixing which occurred for 90 minutes at $80 \mathrm{rpm}$. This was done at $40^{\circ} \mathrm{C}$ and at $60^{\circ} \mathrm{C}$ to observe the effect that temperature has on the reduction of the conductivity in the water. Results showed that the reduction of conductivity levels was higher at $60^{\circ} \mathrm{C}$. This is due to the increase of the rate of reaction with an increase in temperature. Thus the treatment of $\mathrm{RO}$ - reject is preferred at $60^{\circ} \mathrm{C}$ to achieve effective removal of ions with the potential of scale formation.
\end{abstract}

Index Terms - Conductivity removal, Lime softening, Temperature effect

\section{INTRODUCTION}

South Africa is an arid country with an average rainfall of 492 $\mathrm{mm}$, more or less half of the $985 \mathrm{~mm}$ average rainfall worldwide. An estimation was made that the supply of water will be inferior to the water demand by 2025 , hence the prospect of water shortage problems in the future [1-12]. Surface water is used by Eskom for several purposes, including in the cooling systems.

Manuscript received October 03, 2018. This work was supported in part by the North West University and Eskom.

JC van der Linde is with the Water Pollution Monitoring and Remediation Initiatives Research Group at the school of Chemical and Minerals Engineering, North West University, South Africa.

E Fosso-Kankeu is with the Water Pollution Monitoring and Remediation Initiatives Research Group at the school of Chemical and Minerals Engineering, North West university, South Africa.

G Gericke is with the Eskom research facility, Rosherville, South Africa.

F Waanders is with the Water Pollution Monitoring and Remediation Initiatives Research Group at the school of Chemical and Minerals Engineering, North West university, South Africa.

T. Tamane is with the Eskom research facility, Rosherville, South Africa.
The highly saline water resulting from such systems is often treated through chemical methods and reverse osmosis (RO) [13-20]. The reject from reverse osmosis contains high amount of ions, therefore requiring treatment prior to further passing through the RO membrane. The RO-reject from the Grootvlei power station situated near Balfour, Mpumalanga, was considered in this study.

Reverse osmosis is used to remove dissolved solids from the water through a semipermeable membrane. Several scaling agents such as calcium and magnesium compounds are unable to pass through the membrane. The brine that contains these particles is the RO-Reject. This brine can be reused in the cooling system if treated; this will allow the plant to reduce water intake from the environment [20]. The above mentioned scaling agents should be removed from the water as scaling can negatively influence the efficiency of downstream processes such as heat exchange. Flocculation and crystallization were used to achieve the removal of these scaling agents. Rheofloc, an inorganic polyamine was used in conjunction with calcium hydroxide (lime) and a polymeric coagulant [21].

The polyamines are cationic polymers with medium molecular weight, which are mostly linear. They are soluble and can be used over wide $\mathrm{pH}$ ranges. This is important as the $\mathrm{pH}$ should be increased to a value of 10.1. The molecules have a lengthy structure which enables them to wrap impurities together to increase floc size and weight. This promotes settling and stability of the flocs [22-28].

The lime is used to increase the $\mathrm{pH}$ to 10.1. This ensures that the calcium and magnesium ions are insoluble in the water. Thus making it possible to remove these ions from the water. At a $\mathrm{pH}$ of 10.1 the $\mathrm{Mg}(\mathrm{OH})_{2}$ becomes insoluble and precipitate. Along with the above mentioned polymeric and polyquarternary amines, strontium, calcium and magnesium can be removed by making insoluble larger and heavier [29].

The conductivity will be used to observe the effect of temperature on the efficiency of the flocculation and crystallization process. Conductivity is the potential for a substance to conduct or transmit heat, electricity and sound. The presence of metal ions increases the conductivity of a solution. Thus a reduction in the conductivity indicates the removal of metal ions in water. The conductivity is measured with a probe that is connected to a conductivity meter and measured in Siemens per centimeter $(\mathrm{S} / \mathrm{cm})[30]$. To use water in the cooling system of a power plant, the conductivity should be less than 4 $\mathrm{mS} / \mathrm{cm}$. 


\section{Methodology}

The jar test method was used to conduct these experiments. It consists of a six paddle stirrer with a variable speed motor. A simplified schematic illustration can be seen below:

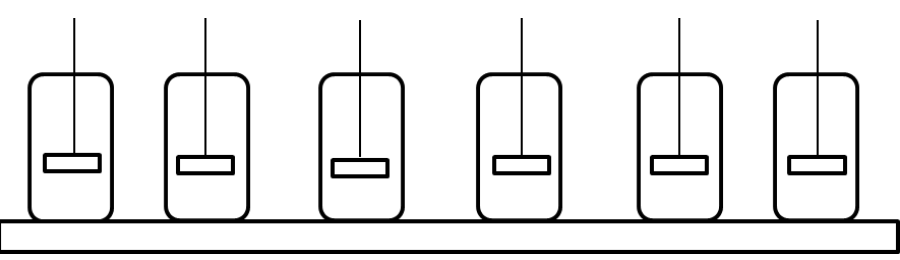

Fig 1: Representation of the jar test apparatus

The jar test is connected to a water bath to ensure that the temperature of the samples remain constant.

Six $1000 \mathrm{ml}$ beakers were each filled with $500 \mathrm{ml}$ of RO-Reject sample water. These beakers were placed in the jar test where they were kept until a temperature of $40^{\circ} \mathrm{C}$ was reached. Thereafter the coagulant (Rheofloc 5023) was added into the beakers. Each beaker contained a different dosage of the coagulant. These dosages were $0.2 \mathrm{ppm}, 0.5 \mathrm{ppm}, 0.7 \mathrm{ppm}, 2 \mathrm{ppm}$, $5 \mathrm{ppm}$ and $7 \mathrm{ppm}$.

The flocculant (Rheofloc 5414) was added. The dosage was kept constant in each beaker, $0.2 \mathrm{ppm}$. Rapid mixing then occurred for 5 minutes at 240rpm. Thereafter slow mixing occurred for 90 minutes at $80 \mathrm{rpm}$. At the start of the slow mixing period, lime was added, $220 \mathrm{ppm}$. This dosage was necessary to achieve the set $\mathrm{pH}$. After the slow mixing a settling time of 30 minutes occurred. The above mentioned method was used for another three different flocculant dosages $(0.5 \mathrm{ppm}$, $1 \mathrm{ppm}$ and $7 \mathrm{ppm})$. This whole process was repeated at $60^{\circ} \mathrm{C}$.

The $\mathrm{pH}$ was measured to ensure that it was high enough for optimal removal of scaling agents.

The conductivity was measured by inserting the probe into the sample.

\section{RESULTS AND DISCUSSION}

The results of the conductivity tests can be seen in the tables below:

TABLE I: CONDUCTIVITY RESULTS WITH A 0.2 PPM FLOCCULANT DOSAGE @ $40^{\circ}$ $\mathrm{C}$

\begin{tabular}{|l|l|l|}
\hline \multicolumn{3}{|c|}{ 0.2 ppm flocculant dosage $@ \mathbf{4 0}{ }^{\circ} \mathrm{C}$} \\
\hline $\begin{array}{l}\text { Coagulant dosage } \\
(\mathrm{ppm})\end{array}$ & $\begin{array}{l}\text { Conductivity after } \\
\text { treatment }(\mathrm{mS} / \mathrm{cm})\end{array}$ & $\begin{array}{l}\text { Conductivity } \\
\text { removal (\%) }\end{array}$ \\
\hline 0.2 & 3.61 & 8 \\
\hline 0.5 & 3.64 & 7 \\
\hline 0.7 & 3.62 & 8 \\
\hline 2 & 3.60 & 8 \\
\hline 5 & 3.60 & 8 \\
\hline 7 & 3.66 & 7 \\
\hline
\end{tabular}

Table illustrates the conductivity and conductivity removal at $40^{\circ} \mathrm{C}$ and a $0.2 \mathrm{ppm}$ flocculant dosage. It can be compared to the same dosage at $60^{\circ} \mathrm{C}$. It should be noted that the starting conductivity of the water differs between the $40^{\circ} \mathrm{C}$ and $60^{\circ} \mathrm{C}$ tests as the water was collected at different times through the year. Thus the conductivity removal is the important parameter to consider.

TABLE II: CONDUCTIVITY RESULTS WITH A 0.2 PPM FLOCCULANT DOSAGE @ $60^{\circ} \mathrm{C}$

\begin{tabular}{|l|l|l|}
\hline \multicolumn{3}{|c|}{$\mathbf{0 . 2}$ ppm flocculant dosage @ $60{ }^{\circ} \mathrm{C}$} \\
\hline $\begin{array}{l}\text { Coagulant dosage } \\
(\mathrm{ppm})\end{array}$ & $\begin{array}{l}\text { Conductivity after } \\
\text { treatment }(\mathrm{mS} / \mathrm{cm})\end{array}$ & $\begin{array}{l}\text { Conductivity } \\
\text { removal (\%) }\end{array}$ \\
\hline 0.2 & 3.45 & 46 \\
\hline 0.5 & 3.43 & 46 \\
\hline 0.7 & 3.44 & 46 \\
\hline 2 & 3.43 & 46 \\
\hline 5 & 3.42 & 46 \\
\hline 7 & 3.40 & 47 \\
\hline
\end{tabular}

It can clearly be seen that the increase in temperature has an enormous effect on the conductivity removal in RO-Reject water. The conductivity of the treated water is also low enough to be suitable for use in the cooling water system.

Table is the representation of the conductivity and conductivity removal with a $0.5 \mathrm{ppm}$ flocculant dosage at $40^{\circ} \mathrm{C}$.

TABLE III: CONDUCTIVITY RESULTS WITH A 0.5 PPM FLOCCULANT DOSAGE @ $40^{\circ} \mathrm{C}$

\begin{tabular}{|l|l|l|}
\hline \multicolumn{3}{|c|}{$\mathbf{0 . 5}$ ppm flocculant dosage @ 40 ${ }^{\circ} \mathrm{C}$} \\
\hline $\begin{array}{l}\text { Coagulant dosage } \\
(\mathrm{ppm})\end{array}$ & $\begin{array}{l}\text { Conductivity after } \\
\text { treatment (mS/cm) }\end{array}$ & $\begin{array}{l}\text { Conductivity } \\
\text { removal (\%) }\end{array}$ \\
\hline 0.2 & 3.69 & 7 \\
\hline 0.5 & 3.68 & 7 \\
\hline 0.7 & 3.68 & 7 \\
\hline 2 & 3.65 & 8 \\
\hline 5 & 3.63 & 8 \\
\hline 7 & 3.62 & 8 \\
\hline
\end{tabular}

This can be compared to the same flocculant dosage at $60^{\circ} \mathrm{C}$ as can be seen in Table .

TABLE IV: CONDUCTIVITY RESULTS WITH A 0.5 PPM FLOCCULANT DOSAGE @ $60^{\circ} \mathrm{C}$

\begin{tabular}{|l|l|l|}
\hline \multicolumn{3}{|c|}{ 0.5 ppm flocculant dosage $@ 60{ }^{\circ} \mathrm{C}$} \\
\hline $\begin{array}{l}\text { Coagulant dosage } \\
(\mathrm{ppm})\end{array}$ & $\begin{array}{l}\text { Conductivity after } \\
\text { treatment (mS/cm) }\end{array}$ & $\begin{array}{l}\text { Conductivity } \\
\text { removal (\%) }\end{array}$ \\
\hline 0.2 & 4.32 & 32 \\
\hline 0.5 & 4.38 & 31 \\
\hline 0.7 & 4.41 & 31 \\
\hline 2 & 4.41 & 31 \\
\hline 5 & 4.39 & 31 \\
\hline 7 & 4.37 & 32 \\
\hline
\end{tabular}

As can be seen from Table, once again the dosages at $60^{\circ} \mathrm{C}$ were more efficient; however, the treated water cannot be used in the cooling system as the conductivity is more than $4 \mathrm{mS} / \mathrm{cm}$.

The $1 \mathrm{ppm}$ flocculant dosage at $40^{\circ} \mathrm{C}$ can be seen in Table . 
TABLE V: CONDUCTIVITY RESUlts WITH a 1 PPM FLOCCULANT DOSAGE @ $40^{\circ} \mathrm{C}$

\begin{tabular}{|l|l|l|}
\hline \multicolumn{3}{|c|}{ 1 ppm flocculant dosage $@ 40{ }^{\circ} \mathrm{C}$} \\
\hline $\begin{array}{l}\text { Coagulant dosage } \\
(\mathrm{ppm})\end{array}$ & $\begin{array}{l}\text { Conductivity after } \\
\text { treatment (mS/cm) }\end{array}$ & $\begin{array}{l}\text { Conductivity } \\
\text { removal }(\%)\end{array}$ \\
\hline 0.2 & 3.65 & 8 \\
\hline 0.5 & 3.65 & 8 \\
\hline 0.7 & 3.65 & 8 \\
\hline 2 & 3.57 & 9 \\
\hline 5 & 3.71 & 6 \\
\hline 7 & 3.72 & 6 \\
\hline
\end{tabular}

This can be compared to the same flocculant dosage at $60^{\circ} \mathrm{C}$ as can be seen in Table.

TABLE VI: CONDUCTIVITY RESULTS WITH A 1 PPM FLOCCULANT DOSAGE @ $60^{\circ} \mathrm{C}$

\begin{tabular}{|l|l|l|}
\hline \multicolumn{3}{|c|}{1 ppm flocculant dosage @ $60{ }^{\circ} \mathrm{C}$} \\
\hline $\begin{array}{l}\text { Coagulant dosage } \\
(\mathrm{ppm})\end{array}$ & $\begin{array}{l}\text { Conductivity after } \\
\text { treatment(mS/cm) }\end{array}$ & $\begin{array}{l}\text { Conductivity } \\
\text { removal }(\%)\end{array}$ \\
\hline 0.2 & 3.95 & 38 \\
\hline 0.5 & 3.94 & 38 \\
\hline 0.7 & 3.96 & 38 \\
\hline 2 & 3.96 & 38 \\
\hline 5 & 3.94 & 38 \\
\hline 7 & 3.84 & 40 \\
\hline
\end{tabular}

At $60^{\circ} \mathrm{C}$, there is a conductivity removal increase of more or less $30 \%$. The conductivity is also low enough to use the water in the cooling system. Thus implying that with a flocculant dosage of $1 \mathrm{ppm}, 60^{\circ} \mathrm{C}$ is more efficient than $40^{\circ} \mathrm{C}$.

The last flocculant dosage that was used was $7 \mathrm{ppm}$. The $7 \mathrm{ppm}$ flocculant dosage results at $40^{\circ} \mathrm{C}$ can be observed in Table .

TABLE VII: CONDUCTIVITY RESULTS WITH A 7 PPM FLOCCULANT DOSAGE @ $40^{\circ} \mathrm{C}$

\begin{tabular}{|l|l|l|}
\hline \multicolumn{3}{|c|}{7 ppm flocculant dosage $@ \mathbf{4 0}{ }^{\circ} \mathrm{C}$} \\
\hline $\begin{array}{l}\text { Coagulant dosage } \\
(\mathrm{ppm})\end{array}$ & $\begin{array}{l}\text { Conductivity after } \\
\text { treatment (mS/cm) }\end{array}$ & $\begin{array}{l}\text { Conductivity } \\
\text { removal (\%) }\end{array}$ \\
\hline 0.2 & 3.71 & 7 \\
\hline 0.5 & 3.71 & 7 \\
\hline 0.7 & 3.75 & 5 \\
\hline 2 & 3.76 & 6 \\
\hline 5 & 3.76 & 6 \\
\hline 7 & 3.72 & 6 \\
\hline
\end{tabular}

This can be compared to the $7 \mathrm{ppm}$ flocculant dosage at $60^{\circ} \mathrm{C}$ as can be observed in Table.
TABLE VIII: CONDUCTIVITY RESULTS WITH A 7 PPM FLOCCULANT DOSAGE @ $60^{\circ} \mathrm{C}$

\begin{tabular}{|l|l|l|}
\hline \multicolumn{3}{|c|}{7 ppm flocculant dosage @60 ${ }^{\circ} \mathrm{C}$} \\
\hline $\begin{array}{l}\text { Coagulant dosage } \\
(\mathrm{ppm})\end{array}$ & $\begin{array}{l}\text { Conductivity after } \\
\text { treatment }(\mathrm{mS} / \mathrm{cm})\end{array}$ & $\begin{array}{l}\text { Conductivity } \\
\text { removal }(\%)\end{array}$ \\
\hline 0.2 & 3.94 & 38 \\
\hline 0.5 & 3.97 & 38 \\
\hline 0.7 & 3.94 & 38 \\
\hline 2 & 3.98 & 38 \\
\hline 5 & 3.96 & 38 \\
\hline 7 & 3.96 & 38 \\
\hline
\end{tabular}

As can be seen from table, the conductivity of the treated water is less than $4 \mathrm{mS} / \mathrm{cm}$. Thus this water can be used in the cooling system. The higher temperature has a greater effect on the conductivity remobval as well.

A trend can be seen in the figure below on the effect different coagulant and flocculant dosages have on the conductivity removal at $40^{\circ} \mathrm{C}$ and at $60^{\circ} \mathrm{C}$.

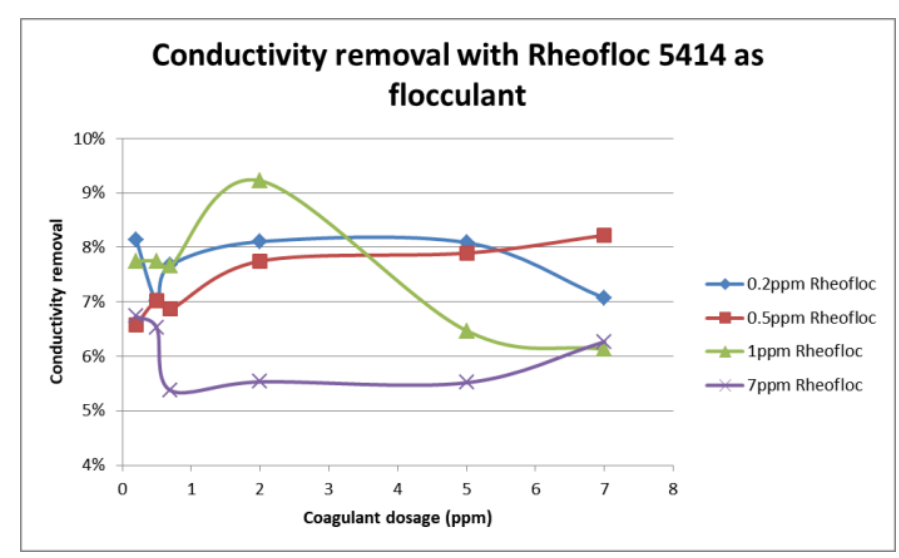

Fig 2: Conductivity removal @ $40^{\circ} \mathrm{C}$

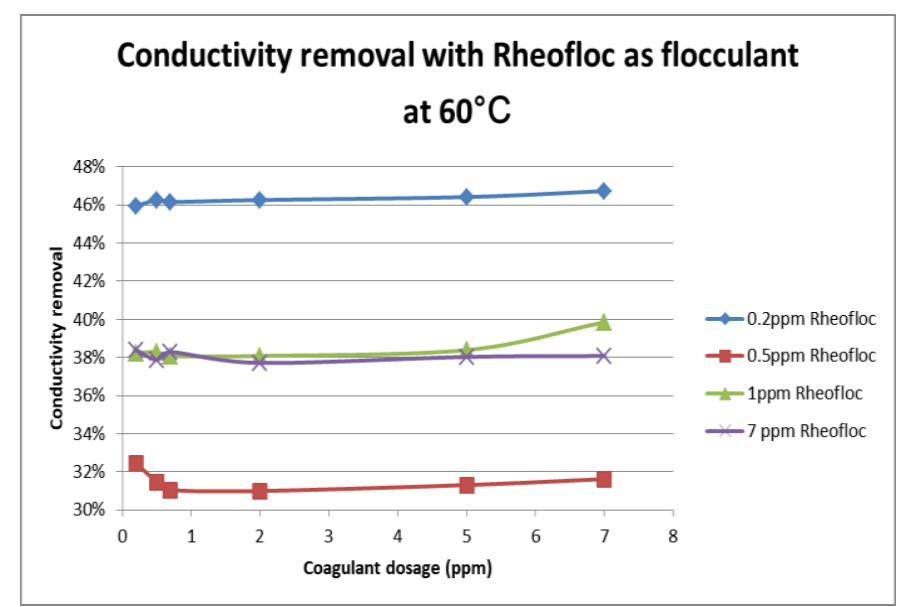

Fig 3: Conductivity removal @ 40 $\mathrm{C}$

As can be seen from Figure 1 and Figure 2, the conductivity removal is more efficient at higher temperatures, as well as less of the flocculant is needed at higher temperatures. This confirms 
the literature by [31] that hot lime softening is more efficient than cold lime softening due to the reduction in solubility of calcium, magnesium, barium and strontium with an increase in temperature. Precipitation of these ions will occur more readily with the decrease in solubility which in turn will reduce the dissolved solids in the water, reducing the conductivity in the water.

\section{CONCLUSION AND RECOMMENDATIONS}

There is a clear effect of temperature on the conductivity removal when using Rheofloc as coagulant and flocculant in conjunction with lime. For optimal conductivity removal, 0.2 ppm Rheofloc 5414 and $0.2 \mathrm{ppm}$ Rheofloc 5023 should be used at $60^{\circ} \mathrm{C}$ in conjunction with $220 \mathrm{ppm}$ lime. With this dosage, the conductivity of $3.45 \mathrm{mS} / \mathrm{cm}$ was measured, which is below the required $4 \mathrm{mS} / \mathrm{cm}$. This resulted into a conductivity reduction of $46 \%$, therefore decreasing the amount of ions in solution. Thus indirectly implying that the chances for scaling could to occur have been reduced by half.

Recommendations include that other flocculants should be tested to observe if a better decrease in conductivity can be achieved and to test if using other chemicals such as sodium hydroxide, can be used to increase the $\mathrm{pH}$ faster.

\section{REFERENCES}

[1] R. Water. (2017, 28 March). Water situation in South Africa. Available: www.waterwise.co.za/water/environment/situation.html

[2] E. Fosso-Kankeu, P. Jagals, H. Du Preez, Exposure of rural households to toxic cyanobacteria in container-stored water. Water SA, Vol. 34, no. 5, pp. 631-636, 2008.

[3] E. Fosso-Kankeu, A. Mulaba-Bafubiandi, B.B. Mamba, T.G. Barnard, Mitigation of $\mathrm{Ca}, \mathrm{Fe}$, and $\mathrm{Mg}$ loads in surface waters around mining areas using indigenous microorganism strains. Journal of Physics and Chemistry of the Earth, Vol. 34, pp. 825-829, 2009. https://doi.org/10.1016/j.pce.2009.07.005

[4] E. Fosso-Kankeu, H. Du Preez, P. Jagals, The health implication of relationships between bacterial endotoxin, cyanobacteria, coliforms and water stored in domestic containers of rural households in South Africa. Journal of Water and Health, Vol. 8, no. 4, pp. 601-610, 2010. https://doi.org/10.2166/wh.2010.094

[5] F. Waanders, M. Nel, E. Fosso-Kankeu, Adsorption potential of bentonite clay and attapulgite applied for the desalination of sea water. $6^{\text {th }}$ International Conference on Green Technology, Renewable Energy and Environmental Engineering (ICGTREEE'2014). 27-28 November 2014, Cape Town-South Africa. Editors: Muzenda E. and Sandhu S. ISBN: 978-93-84468-08-8. Pp 275-279. 2014.

[6] E. Fosso-Kankeu, F. Waanders, M. Reitz, Selective adsorption of heavy and light metals by natural zeolites. $6^{\text {th }}$ International Conference on Green Technology, Renewable Energy and Environmental Engineering (ICGTREEE'2014). 27-28 November 2014, Cape Town-South Africa. (Award Winning Paper). Editors: Muzenda E. and Sandhu S. ISBN: 978-93-84468-08-8. Pp 271-274. 2014.

[7] E. Fosso-Kankeu, S. Marx, J.A. Ribberink, J.P.J. Van Den Bergh, Co-digestion of Sweet Sorghum Bagasse with Scientific and Crude Glycerols for Electricity Generation. $6^{\text {th }}$ International Conference on Green Technology, Renewable Energy and Environmental Engineering (ICGTREEE'2014). 27-28 November 2014, Cape Town-South Africa. (Award Winning Paper). Editors: Muzenda E. and Sandhu S. ISBN: 978-93-84468-08-8. Pp 265-270. 2014.

[8] E. Fosso-Kankeu, S. Marx, A. Meyer, Susceptibility of Saccharomyces cerevisiae to inhibitors and impact on bioethanol production yield. $6^{\text {th }}$ International Conference on Green Technology, Renewable Energy and Environmental Engineering (ICGTREEE'2014). 27-28 November 2014, Cape Town-South Africa. Editors: Muzenda E. and Sandhu S. ISBN: 978-93-84468-08-8. Pp 261-264. 2014.
[9] E. Fosso-Kankeu, F. Waanders, C. Fraser, Bentonite clay adsorption affinity for anionic and cationic dyes. $6^{\text {th }}$ International Conference on Green Technology, Renewable Energy and Environmental Engineering (ICGTREEE'2014). 27-28 November 2014, Cape Town-South Africa. Editors: Muzenda E. and Sandhu S. ISBN: 978-93-84468-08-8. Pp 257-260. Pp 257-260. 2014.

[10] E. Fosso-Kankeu, C.M. Van der Berg, F.B. Waanders, Physico-chemical activation of South African bentonite clay and impact on metal adsorption capacity. $6^{\text {th }}$ International Conference on Green Technology, Renewable Energy and Environmental Engineering (ICGTREEE'2014). 27-28 November 2014, Cape Town-South Africa. Editors: Muzenda E. and Sandhu S. ISBN: 978-93-84468-08-8. Pp 247-252. 2014.

[11] E. Fosso-Kankeu; O. Ntwampe, F. Waanders, and A. Webster, The Performance of Polyaluminium Chloride and Bentonite clay Coagulant in the Removal of Cationic and Anionic Dyes. $7^{\text {th }}$ International Conference on Latest Trends in Engineering and Technology (ICLTET' 2015), November 26-27, 2015 Irene, Pretoria (South Africa). Editors: E. Muzenda and T Yingthawornsuk. ISBN: 978-93-84422-58-5. 2015.

[12] E. Fosso-Kankeu, A. Manyatshe, D. van der Berg, N. Lemmer, F. Waanders, and H. Tutu, Contaminants in Sediments across the Mooi and Vaal Rivers Network in The Vicinity of Potchefstroom. $7^{\text {th }}$ International Conference on Latest Trends in Engineering and Technology (ICLTET' 2015), November 26-27, 2015 Irene, Pretoria (South Africa). Editors: E. Muzenda and T Yingthawornsuk. ISBN: 978-93-84422-58-5. 2015.

[13] E. Fosso-Kankeu, J. Redelinghuys, F. Waanders, D. Rogers, D. Bruinsma, G. Gericke, Determination of water evaporation rate in an assembled bench scale MED and impact of anti-scaling agents on the morphology of scale. International Conference on Advances in Science, Engineering, Technology and Natural Resources (ICASETNR-16) Nov. 24-25, 2016, Parys - South Africa. ISBN: 978-93-84468-79-8. 2016.

[14] E. Fosso-Kankeu, F. Waanders, D. Van Niekerk, D. Rogers, G. Gericke, Treatment of raw and processed waters from coal power plant using PACl supplemented with cationic organic polymer and bentonite. International Conference on Advances in Science, Engineering, Technology and Natural Resources (ICASETNR-16) Nov. 24-25, 2016, Parys - South Africa. ISBN: 978-93-84468-79-8. 2016.

[15] E. Fosso-Kankeu, F. Waanders, R. Swiegers, I.O. Ntwampe, D. Rogers, G. Gericke, Impact of the physico-chemical properties of water on the flocculation performance of lime, clay and other polymers. International Conference on Advances in Science, Engineering, Technology and Natural Resources (ICASETNR-16) Nov. 24-25, 2016, Parys - South Africa. ISBN: 978-93-84468-79-8. 2016.

[16] E. Fosso-Kankeu, F.B. Waanders, G. Gericke, N. Lemmer, L.M. Dreyer and J. van der Linde, Investigation of the potential of monomeric and polymeric coagulants in the treatment of raw water used at a coal-fired power station. $9^{\text {th }}$ Int'l Conference on Advances in Science, Engineering, Technology \& Waste Management (ASETWM-17). 27-28 November 2017, Parys, South Africa. Editors: F. Waanders, E. Fosso-Kankeu, B. Topcuoglu, M. Plaisent, Y. Thaweesak. ISBN: 978-81-934174-6-1. Pp. 44-48. 2017.

[17] J.C. van der Linde, E. Fosso-Kankeu, G. Gericke, N. Lemmer, and F. Waanders, Removal of Total Hardness and Alkalinity from RO - reject water. $9^{\text {th }}$ Int'l Conference on Advances in Science, Engineering, Technology \& Waste Management (ASETWM-17). 27-28 November 2017, Parys, South Africa. Editors: F. Waanders, E. Fosso-Kankeu, B. Topcuoglu, M. Plaisent, Y. Thaweesak. ISBN: 978-81-934174-6-1. Pp. 147-151. 2017.

[18] E. Fosso-Kankeu, C.E. Brider, J. Redelinghuys, G. Gericke, N. Lemmer, F. Waanders, Determination of suitable anti-scaling agent to inhibit scale formation of water processed in coal power plant system. $9^{\text {th }}$ Int'l Conference on Advances in Science, Engineering, Technology \& Waste Management (ASETWM-17). 27-28 November 2017, Parys, South Africa. Editors: F. Waanders, E. Fosso-Kankeu, B. Topcuoglu, M. Plaisent, Y. Thaweesak. ISBN: 978-81-934174-6-1. Pp. 30-36. 2017.

[19] J. Redelinghuys, E. Fosso-Kankeu, F. Waanders, D. Rogers, G. Gericke, Scaling conditions inside improved bench-scale single effect vacuum evaporator. $9^{\text {th }}$ Int'l Conference on Advances in Science, Engineering, Technology \& Waste Management (ASETWM-17). 27-28 November 2017, Parys, South Africa. Editors: F. Waanders, E. Fosso-Kankeu, B. Topcuoglu, M. Plaisent, Y. Thaweesak. ISBN: 978-81-934174-6-1. Pp. 169-174. 2017. 
[20] E. Evaporators. (2017, 13 September). Using Evaporators for Reverse Osmosis Reject Water. Available: http://www.evaporator.com/reverse-osmosis-reject.

[21] (2017, 11 February). Difference Between Crystallization and Precipitation. $\quad$ Available: $\mathrm{http}: / / \mathrm{www}$.differencebetween.com/difference-between-crystallization-a nd-vs-precipitation/.

[22] S. Chesters, E. Darton, S. Gallego, and F. Vigo, "The safe use of cationic flocculants with reverse osmosis membranes," Desalination and Water Treatment, vol. 6, pp. 144-151, 2009. https://doi.org/10.5004/dwt.2009.660

[23] E. Fosso-Kankeu, F. Waanders, Metal Ions Adsorption Affinity of Clay Materials from the North West Province of South Africa. An Interdisciplinary Response to Mine Water Challenges. International Mine Water Conference, August 2014 Xuzhou China. Editors, Sui, Sun \& Wang (Eds). 2014 China University of Mining andTechnology Press, Xuzhou, ISBN: 978-7-5646-2437-8. Pp374-378. 2014.

[24] I.O. Ntwampe, F.B. Waanders, E. Fosso-Kankeu, J.R. Bunt, Reaction ynamics of iron and aluminium salts dosage in AMD using shaking as an alternative technique in the destabilization-hydrolysis process. International Scientific Research Journal. Vol. 1, no. 8, pp. 5-23, 2015.

[25] E. Fosso-Kankeu; O. Ntwampe, F. Waanders, and A. Webster, The Performance of Polyaluminium Chloride and Bentonite clay Coagulant in the Removal of Cationic and Anionic Dyes. ${ }^{\text {th }}$ International Conference on Latest Trends in Engineering and Technology (ICLTET' 2015), November 26-27, 2015 Irene, Pretoria (South Africa). Editors: E. Muzenda and T Yingthawornsuk. ISBN: 978-93-84422-58-5. 2015.

[26] E. Fosso-Kankeu, H. Mittal, F. Waanders, I.O. Ntwampe, S.S. Ray, Preparation and characterization of gum karaya hydrogel nanocomposite flocculant for metal ions removal from mine effluents. International Journal of Environmental Science and Technology. Vol. 13, pp. 711-724, 2016. https://doi.org/10.1007/s13762-015-0915-x

[27] E. Fosso-Kankeu, A. Webster, I.O. Ntwampe, F.B. Waanders, Coagulation/flocculation potential of polyaluminium chloride and bentonite clay tested in the removal of methyl red and crystal violet. Arabian Journal for Science and Engineering. DOI 10.1007/s13369-016-2244-x. 2016.

[28] E. Fosso-Kankeu, F. Waanders, A.F. Mulaba-Bafubiandi, A.K. Mishra. 2016. Flocculation performances of polymers and nanomaterials for the treatment of industrial wastewaters. In A.K. Mishra (ed). 2016. Smart Materials for Waste Water Applications. Wiley Scrivener. ISBN: 9781119041184. Pp $213-235$.

[29] A. J. O'Donnell, D. A. Lytle, S. Harmon, K. Vu, H. Chait, and D. D. Dionysiou, "Removal of strontium from drinking water by conventional treatment and lime softening in bench-scale studies," Water Research, vol. 103, pp. 319-333, 2016/10/15/ 2016.

[30] Lenntech. (2017, 4 September). Water Conductivity. Available: http://www.lenntech.com/applications/ultrapure/conductivity/water-con ductivity.htm

[31] G. P. Water. (2012, 8 October). Chapter 7: Precipitation softening. Available: https://www.suezwatertechnologies.com/handbook/ext_treatment/ch_7_ precipitation.jsp\#Cold\%20lime\%20softening 